\title{
IT i uddannelsessystemet - med hvilket sigte?
}

\author{
Helle Mathiasen, professor, leder af Forskningscenter for it E laering, Institut for informations og \\ medievidenskab, Aarhus Universitet
}

Camilla Kolsen de Wit, forsknings- og innovationschef, Alexandra Instituttet

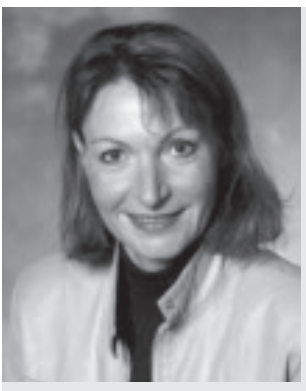

Helle Mathiasen, professor ved Institut for informations- og medievidenskab, leder af Forskningscenter for it \& læring, Aarhus Universitet.

Pt. forskningsleder på projektet Undervisningsorganisering, -former og -medier. Deltager endvidere i projektet Sammenhæng mellem mål, prøve og besvarelse i uddannelsen til studentereksamen samt i projektet It-faglighed i de gymnasiale uddannelser og samarbejde med erhvervslivet, en vej til universitetets it-uddannelser?

Yderligere oplysninger: http://person.au.dk/da/hema@im

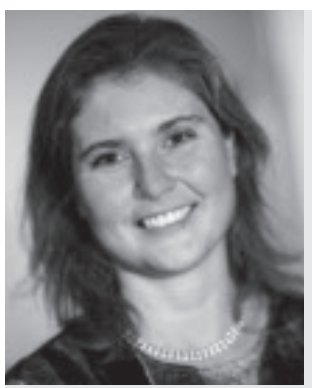

Camilla Kølsen de Wit, cand.mag., ph.d., forsknings- og innovationschef i Forretningsforståelse på Alexandra Instituttet.

\section{Reviewet artikel}

Erhvervslivet eftersporger it-kompetencer på universitetsniveau og universiteterne har den nodvendige kapacitet til at levere kandidater med de efterspurgte it-kompetencer. Dette er dokumenteret $i$ en undersegelse udfort både $i 2009$ og 2010 af It-forum. De nyeste, endnu upublicerede tal fra feb. 2010 indikerer, at det er vanskeligst for virksomhederne at fă it-medarbejdere med lange videregående uddannelser ${ }^{1}$. Genstandsfeltet er komplekst, hvilket fremgår af rapporten Overgangsproblemer som udfordringer i uddannelsessystemet (2009)2. Artikelen fokuserer på et casestudie omhandlende uddannelsessystemets styrende dokumenter med fokus på it samt aktorers iagttagelser af promisser for udvikling af it-kompetencer og for valg af it-uddannelse. Valget af case kan ses som en invitation til fortsat debat om uddannelsessystemets muligheder for at medvirke til at motivere til valg af videregående it-uddannelser på universitetsniveau.

\section{Indledning}

Artiklen vil præsentere resultaterne af en analyse af udvalgte styredokumenter og casebaserede undersøgelsesresultater indeholdende elevers og studerendes iagttagelser af deres it-kompetencer samt forskeres og udvalgte ressourcepersoners iagttagelse af elevers itkompetencer. Med hensyn til it-kompetencer viser de empiriske forstudier, at det er konstruktivt for debatten at skelne mellem it-anvendelse og it-faglighed. Denne skelnen anser vi som pertinent for en fremadrettet debat om it-kompetencer i uddannelsessystemet. Begreberne vil blive udfoldet $i$ artiklen.

Undersøgelsen er et første forsøg på at tematisere it i uddannelsessystemet i et længdeperspektiv. Projektet har af pragmatiske grunde måttet foretage nogle valg $\mathrm{i}$ forhold til omfanget af undersøgelsesrammen, hvilket betyder, at projektets empiriske genstandsfelt er trukket fra grundskolens afgangsklasser over det almene gymnasium og til it-uddannelser på universitetet i Danmark. I dette længdeperspektiv er der igen foretaget nogle valg, således at tyngden i nærværende artikel vil blive lagt på overgangsudfordringer fra det almene gymnasium til universitetets it-uddannelser.

Den grundlæggende antagelse er, at it-kompetencer kan være nyttige og nødvendige $i$ grundskolen, gymnasiet (stx) og på det universitære niveau. Det drejer sig i bredeste forstand om it-færdigheder og it-viden og det at kunne bruge viden og færdigheder i nye kontekster.

Der er ikke tale om en normativ tilgang, i den forstand, at »it ses som losning på uddannelsessystemets problemer«, men om en tilgang, der søger viden om faktorer, der kan være betydende for, i hvilken grad elever og studerende oplever it-anvendelse og it-faglighed som meningsfuldt, som noget de vælger at aktualisere i forbindelse med deres uddannelsesrelaterede aktiviteter.

Artiklens ledespørgsmål er: Kan der iagttages en 
progression i uddannelsessystemet for it-anvendelse og it-faglighed? Spørgsmålet udspringer af en antagelse om, at progression i it-anvendelse og it-faglighed i uddannelsessystemet for universitetsniveauet kan være en ansporende faktor, når valg af it-uddannelser på universitetsniveau skal foretages.

Vi har valgt at fokusere på rammesætningen $\mathrm{i}$ form af uddannelsessystemets formelle styredokumenter samt på aktørers iagttagelser af egne og andres it-kompetencer og uddannelsesvalg. Casen fokuserer på progression i it-anvendelse og it-faglighed på langs i uddannelsessystemet via interviews af elever, studerende, forskere og undervisere om deres iagttagelser af it-anvendelse, it-faglighed og progression. Dette gør vi velvidende at praksis ikke er en spejling af styredokumenterne og dermed ikke determinerer undervisning, studieaktiviteter og læreprocesser. Disse dokumenter er et udtryk for det politiske systems intentioner, som uddannelsessystemet kan iagttage og håndtere med reference til bl.a. egen kode, funktion og ydelse.

Yderligere skal det pointeres, at de valgte parametre blot er nogle fă ud af en bred vifte af parametre, der har indflydelse på uddannelsesvalg, jf. rapporten Overgangsproblemer som udfordringer $i$ uddannelsessystemet. (Mathiasen, H. et al. 2009 s. 167-170)

\section{Centrale begreber}

\section{Begrebet it:}

It iagttages her som et bredt spekter af informationsteknologi. Begrebet it omfatter overordnet software og hardware. Det betyder, at digitale medier og netmedierede fora er centrale begreber. Disse begreber har adskillige fremtrædelsesformer og funktionaliteter. Den følgende gennemgang af begrebet it anvender den centrale ledeforskel 'it-anvendelse i undervisningen' og 'it som tema for undervisningen', dvs. 'it-faglighed', som f.eks. programmeringsfag og undervisning i specifikke funktionaliteter i et præsentationsprogram. Begreberne, som de fremstår her, er den optik, hvor igennem styredokumenterne analyseres.

\section{It-anvendelse:}

It-anvendelse drejer sig om brugen af it i undervisningen som en læringsressource og et redskab til f.eks. produktion af tekster, videoer, animationer, statistik og baser. Eksempler på it anvendelse i undervisningen kan være værkstøjsprogrammel, fagspecifikke programmer, færdighedstræningsprogrammer, weblogs, konferencesystemer, wikies, mail m.m.Vi inkluderer anvendelse af de nye medieformer (kommunikationsfora) som f.eks. chat, mail, videokonference og hjemmesider på den ene side og på den anden side intenderede mere eller mindre lukkede læringsressourcer som eksempelvis træningsprogrammer og programprodukter til enkelte fag eller til flerfaglige forløb.

\section{It-faglighed:}

It-faglighed fokuserer på it som emne for undervisningen, som f.eks. undervisning i specifikke faciliteter i applikationer. I den it-faglige undervisning kan temaet også være f.eks. metoder til problemløsning og optimering samt programmering, f.eks. af hjemmesider eller systemer/delsystemer. Der indgår endvidere discipliner som matematik, brugergrænsedesign, systemimplementering og discipliner, hvor der arbejdes med implementering af it i en konkret brugssituation enten anskuet fra den individuelle bruger eller fra et organisatorisk synspunkt. It-fagligheden kan ses integreret i fag, og it-fagligheden kan ses i datalogiorienterede fag. På grundskoleniveau er it-fagligheden ofte udmøntet i undervisning $\mathrm{i}$ faciliteter i programmerne, f.eks. i tekstbehandlingsfaciliteter. I de gymnasiale uddannelser (specifikke valgfag) og specielt i datalogisk orienterede studier på universitetet fremstår it-fagligheden som datalogiorienteret, afhængig af konkret uddannelse.

It-faglighed og it-anvendelse er to begreber, der er gensidigt afhængige. Udviklingen af begge er en iterativ proces, hvor færdigheder og viden i en fortsat udvikling kobler sig til udvikling af it-anvendelse og it-faglighed.

\section{Progression:}

Begrebet progression bruges i nærværende sammenhæng som et perspektiv på de styrende dokumenters indholdsformuleringer og kompetencemålbeskrivelser samt $\mathrm{i}$ forbindelse med informanternes ekspliciterede iagttagelser. Grundlæggende kan begrebet beskrives som en fremadskriden. Her vil fokus ligge på en fremadskriden i faglig bredde og dybde, som den iagttages af informanterne og fortolkes af forfatterne Den faglige progression i bredden for it-anvendelse og it-faglighed er operationaliseret som en iagttagelse af, hvordan styredokumenterne fra 1.-9. klasse i grundskolen og 1.-3. gymnasieklasse udvider mængden af forskellige it-programmer og it-værktøjer, der integreres i undervisningen indenfor fagenes faglige opgaver og foki.

Den faglige progression i dybden er operationaliseret som en iagttagelse af, hvordan styredokumenterne omtaler en specialisering af it-anvendelsen og it-fagligheden uafhængigt af de faglige problemstillinger i fagene.

\section{System:}

Et grundbegreb i den her anvendte systemteoretisk inspirerede tilgang er begrebet system. Systemer iagttages som operationelt lukkede, selvreferentielle og dermed selvskabende. De fremstår som autonome men ikke autarkiske, hvilket betyder, at systemer er afhængige af deres omverden. Systemer kan således give hinanden "næring«. Et system kan med andre ord forstyrre et andet system, ved at stille sin egenkompleksitet til rådighed som omverden for et andet system.

Sociale systemer (f.eks. holdet) opretholder sig selv 
via kommunikation og psykiske systemer (f.eks. studerende) via bevidsthedsaktiviteter. Disse systemtyper er operationelt lukkede for hinanden i den forstand, at f.eks. tanker ikke forlader psykiske systemer som tanker, men som kommunikative konstruktioner. Kommunikation kan på den anden side ikke genfindes som sådan $\mathrm{i}$ et psykisk system, men som en konstruktion, foretaget af det konkrete psykiske system. Ud fra den ovenfor beskrevne systemteoretiske tilgang (systemer er operationelt lukkede) har vi ikke adgang til hinandens tanker, hinandens erkendelsesprocesser eller de mentale strukturer.

En måde, hvorpå en underviser og en studerende kan øge sin viden om erkendelsesprocesser og mentale strukturer hos hinanden, som de giver sig udtryk i kommunikation og handlinger, er ved at spørge til den enkeltes valg og handlinger. "Hvorfor vælger du at gøre det på den måde? «, "Hvorfor er du interesseret $\mathrm{i}$ netop det? «, »Hvad kunne du forestille dig, at resultatet ville blive?«.

\section{Iagttagelse:}

Luhmann definerer iagttagelse som en skelnen og betegnen (Luhmann, 1988, s. 170) Iagttagelsesbegrebet kædes sammen med begrebet operation, som defineres som forskelsmarkering, (Luhmann, 2000, s. 88,) idet disse to begreber er indbyrdes afhængige.

"Iagttagelse er kun mulig som operation, ligegyldigt hvilket system der er tale om; den kan ikke foregå på anden måde. $P a ̊$ den anden side er en skelnen mellem operation og iagttagelse ligesom enhver skelnen kun mulig som iagttagelse; for iagttagelse er ikke andet end skelnen og betegnelse. Den rene operation er, hvad den altid er; ja, man ville ikke engang uden iagttagelse kunne fastslä, at den er og $i k k e$ snarere ikke er. Vil man iagttage operationer, må man altså skelne. «(Luhmann, 1997, s. 56)

Læseren kan med andre ord ikke forvente et 'sidste' eller 'første' element, når selv, systemers grundelementer, operationer, defineres. Operationer og iagttagelser gøres afhængige af hinanden, og selektion er i den sammenhæng 'nøglen'.

Tidsaspektet er en vigtig parameter. Det gælder også i forbindelse med selve øjeblikket for iagttagelse, idet iagttagelsen så at sige er blind for sin egen skelnen. Iagttagelsen kan ikke på samme tid skelne og markere og samtidig skelne og markere 'sig selv'. Derfor taler Luhmann om en blind plet (Luhmann, 1998, s. 61), som kan iagttages $i$ en efterfølgende iagttagelse, - en iagttagelse af iagttagelsen, en 2. ordens iagttagelse. At det er en 2. ordens iagttagelse gør den ikke mere privilegeret jvf. definitionen, da en 2. ordens iagttagelse altid også er en 1. ordens iagttagelse, eller blot en iagttagelse som defineret af Luhmann. Dette er udgangspunktet for casens empiriske tilgang. Med Luhmanns ord:
"Den gamle opfattelse var, at videnskab var henvist til en rationalitet, der kom den $i$ mode i genstandene. Denne opfattelse er opgivet af transcendentalfilosofien $i$ den $u d$ formning, der foreligger som ontologi. Den blev erstattet af tesen om, at realiteten ikke kan erkendes "an sich «, en tese som korrelerer med inkluderingen af selvreference $i$ 'subjektet'. Reobjektiviseringen af selvreferentielle systemer, som gennemfores her, erkloerer ikke denne tese for falsk, men generaliserer den snarere: Ethvert selvreferentielt system har kun den omverdenskontakt, som den selv muliggør, og ingen omverden »an sich. "(Luhmann, 2000, s. 141)

Alt iagttaget er iagttaget af en iagttager, og dermed iagttagerrelateret. Med denne optik er empiri indsamlet og fortolket.

\section{Empirisk design}

Analyse af styredokumenter er den ene del af den empiriske undersøgelse. Den anden del har fokus på interview af feltets aktører.

Som nævnt, kobles progression med temaerne it-faglighed og it-anvendelse, så der yderligere bliver ledeforskellene it-faglig progression (+/-) og it-anvendelsesprogression (+/-). Denne kobling sker for at fokusere på it-faglighed og it-anvendelse fra grundskole til universitet, med udgangspunkt $i$ at undersøge hvordan de definerede it-begreber dels beskrives i de styringsdokumenter, der er rammesættende for undervisningen fra grundskolen til universitetet og dels opleves udmøntet af bl.a. elever og studerende.

Denne skelnen er foretaget for at reducere kompleksiteten og stille skarpt på netop disse forskelsmarkeringer, vel vidende at sådanne altid generer blinde pletter. Det er vilkårene, når den systemteoretiske optik sættes i spil. "Kompleksitet betyder selektionstvang, selektionstvang betyder kontingens og kontingens betyder risiko. "(Luhmann 2000:62). Med en ekspliciteret optik og begrebssætning er præmisserne for undersøgelsen fremlagt. Denne tilgang kan ikke kortlægge feltet og dermed ikke generalisere udover den konkrete kontekst.

Med hensyn til analysen af styredokumenter, er primært bekendtgørelsestekster for grundskole og det almene gymnasium inddraget. For universitetsuddannelserne er det primært studieordningerne, der er medtaget $\mathrm{i}$ undersøgelsen. De konkrete styredokumenter kan ses i rapporten Overgangsproblemer som udfordringer $i$ uddannelsessystemet Mathiasen, H. et al. 2009, s.173-174 og www.uvm.dk, www.science.au.dk/12852, http:// www.nat.au.dk/13099, http://www.nat.au.dk/13157

Ved analysen af styredokumenterne har optikken været en kategorisering af indholdet i de enkelte fagbeskrivelser med henblik på at finde fag, der kunne tolkes som havende progression mellem sig, fordi deres fagbeskrivelser har overlappende og fremadskridende indhold på tværs af de tre uddannelsesniveauer. Kategoriseringen blev dannet på baggrund af ord og begre- 
ber/sætninger fra styredokumenterne, der er relevante i forhold til begreberne it-faglighed og it-anvendelse (bilag 1). Kriteriet for vurderingen af progression $+/-$ er jvf. den teoretiske optik forskernes iagttagelse og fortolkning, baseret på de definerede begreber.

Interviewdelen baserer sig på informationer indsamlet via interviews med 1) embedsmænd med relation til Undervisningsministeriet (UVM), 2) gymnasielærere med særlige kompetencer inden for feltet, 3) studerende på it-bac, informationsvidenskab og datalogi, $\mathrm{AU}, 4)$ forskere inden for ungdomskultur, it-uddannelser på universitetsniveau og it som læringsressource, 5) grundskoleelever (sluttrinnet), gymnasieelever (2. g'ere, 3. g'ere).

I alt er der foretaget 15 interviews, som er sendt til informanterne, med en opfordring til at give respons på den sendte interviewtekst. Disse responser er medtaget, hvilket betyder, at interview og informantrespons på interviewtekst indgår i den samlede empiri.

I forbindelse med analysen af interviews er følgende analytiske ledeforskelle anvendt. 1. it-faglighed/it-anvendelse, 2. fagspecifik it-anvendelse/generel it-anvendelse, 3. it-anvendelsesprogression/ikke it-anvendelsesprogression og 4. it-faglig progression/ikke it-faglig progression.

Pladsen her giver ikke mulighed for at gengive spørgerammen for interviews, og her må blot henvises til rapporten Overgangsproblemer som udfordringer $i$ uddannelsessystemet Mathiasen, H. et al. 2009, s. 170-173.

\section{Findings}

Det følgende afsnit opsummerer undersøgelsens resultater, hvad angår den formelle rammesætning mht. progression i it-anvendelse og it-faglighed fra grundskole over gymnasiet frem til universitetet samt, hvad informanterne oplever og iagttager af progression.

Analysen af styredokumenterne har fokus på de formelle forventninger til it-anvendelsen og it-fagligheden i uddannelsessystemet. For it-anvendelsen kan der i styredokumenterne iagttages en progression mellem grundskolen og gymnasiet og en progression, der fortsætter indenfor selve gymnasieuddannelsen. Der er iagttaget en progression i bredde og i dybde, hvilket henviser til en formel forventning om, at der anvendes en stadigt stigende variation af it-redskaber i undervisningen (progression i bredden), såvel som det forventes, at programmerne anvendes stadig mere avanceret (progression i dybden), f.eks. en stadig mere avanceret anvendelse af søgemaskinerne på internettet. I sprogfagene på det gymnasiale niveau er der f.eks. fokus på, hvordan it kan indgå som præsentationsstøtte (dansk A), informationssøgning og interaktive programmer $i$ arbejdet med sproglære (dansk A, fransk A, B, tysk, engelsk A, B). Hertil kommer en videreførelse af at bruge it til målrettet kommunikation gennem kendskab til forskellige kommunikationsstrategier knyttet til forskel- lige elektroniske genrer (engelsk A, B).Videndeling og informationssøgning er ikke så markant i sprogfagene som i fagene historie, religion og samfundsfag, hvor internettet og dets kilder forventes aktivt inddraget, dels med henblik på at belyse de faglige problemstillinger (religion og samfundsfag) og dels med henblik på at udvikle en kildekritisk tilgang til internettet (religion og samfundsfag). Dette kan iagttages som en progression og videreudvikling af grundskolens fællesmål, hvor it omtales som en ressource til kommunikation, informationssøgning, dataregistrering mv. Faget mediefag i gymnasiet understreger den forventede progression i it-anvendelse, idet fagets teoretisk-analytiske del er informationssøgning, præsentation og formidling af fagligt stof.

It som læringsressource omfatter anvendelsen af it til at udfolde og fremme faglige problemstillinger, faglig viden og færdigheder. Der kan iagttages en progression i bredden og dybden fra grundskolen til gymnasiet, som f.eks. kommer til udtryk via anvendelsen af it til kommunikation, formidling og videndeling specifik koblet til en faglig problemstilling jvf. bilag 1 .

Efter gymnasieuddannelsen afbrydes progressionen $\mathrm{i}$ it-anvendelsen, idet styredokumenterne for it-uddannelser på universitetsniveauet ikke omtaler it-anvendelsen.

For it-fagligheden giver styredokumenterne et billede af en mulig progression mellem valgfag i grundskolen (tekstbehandling, edb og medier) og it-faglige valgfag $i$ gymnasiet som datalogi, multimedier og informationsteknologi. Styredokumenterne beskriver det som en progression i it-fagligheden, der i højere grad handler om specialiseret brug af applikationer og deres faciliteter (f.eks. håndtering og brug af specielle medie- og designprogrammer), end det handler om træning i f.eks. programmering eller algoritmer. I transitionen mellem gymnasiet og universitetet kan der være en it-faglig progression med afsæt i valgfaget programmering på det gymnasiale niveau, hvor it-faglighed som sin egen disciplin bliver udfoldet og bliver tema for undervisningen. Endelig er der en implicit progression mellem gymnasiet og universitetets it-uddannelser, der baserer sig på fællesfagene matematik og statistik, som er centrale redskabsfag for it-uddannelserne på universitetsniveau. Denne progression iagttages som implicit, fordi den ikke italesættes som it-faglig i styredokumenterne på det gymnasiale niveau.

Da det ikke nødvendigvis er tilfældet, at elever, der i grundskolen har valgt et it-fagligt valgfag, også vælger et it-fagligt valgfag i gymnasiet, kan der ikke konkluderes, at der er tale om progression i dybden. Hvis dette er tilfældet er det for de få promiller, der vælger/kan vælge it-valgfag både i grundskolen og i gymnasiet.

It-faglig progression i dybden kan iagttages indenfor it-uddannelserne på det universitære niveau.

Informanterne giver $\mathrm{i}$ interviewene udtryk for, at de ikke har oplevet for store eller irrelevante krav til 
it-anvendelser, når de er startet i gymnasiet. Når de universitetsstuderende ser tilbage på deres gymnasietid og grundskoletid giver de udtryk for en oplevelse af sammenhæng i forhold til it-anvendelser. Der er for dem ikke et gab mellem it-anvendelser, de husker, de brugte i grundskolen og gymnasiet. Gymnasieelevernes tilbageblik på deres it-anvendelser i grundskolen giver det samme billede, som de universitetsstuderende giver udtryk for. Helt centralt står tekstbehandling til opgaveproduktion, hvor stadig flere funktionaliteter er blevet aktiveret gennem folkeskole og gymnasiet. Powerpoint nævnes endvidere som en applikation, som gradvist er blevet udfoldet $\mathrm{i}$ form af stadig mere avanceret brug. Hvor dybt denne mere avancerede brug er, kan ikke præciseres af elever i grundskolen og gymnasiet. Når det handler om it-fagligheden fra grundskole til universitetet, giver de interviewede elever og studerende udtryk for, at denne faglighed ikke har været i højsædet i grundskolen og i gymnasiet. Specielt den specifikt datalogirelaterede it-faglighed opleves som fraværende. Gymnasielever og universitetsstuderende har vanskeligt ved at pege på undervisning, hvor it som emne har været i fokus. Nogle husker ikke, at de har deltaget $i$ anvendelsesorienteret it-faglig undervisning, og andre har kritiske holdninger til den undervisning, der blev aktualiseret.

Informanternes iagttagelser af it-anvendelse og itfaglighed stemmer overens med analysen af styredokumenterne, når det gælder interviewene med elever og studerende. Der er dog informanter, der giver udtryk for, at specielt progression i dybde er en relativ størrelse. Det gælder primært de interviewede informanter med relation til UVM, gymnasielærere med særlige kompetencer inden for feltet og forskere med fokus på it som læringsressource samt forskere indenfor ituddannelser på universitetsniveau. Disse informanter giver udtryk for at it's potentiale ikke bliver udnyttet i tilstrækkelig grad, og at der med fordel kunne sættes fokus på f.eks. applikationernes mange funktionaliteter, som ikke tematiseres $i$ undervisningen og dermed er ukendte ressourcer for mange elever.

\section{Hvad skal der til? - Invitation til fortsat debat}

Både med hensyn til progression i it-anvendelse og it-faglighed kan der ifølge casen tænkes i videreudvikling af sammenhænge mellem henholdsvis grundskole, gymnasium og universitetets it-uddannelser og dermed fortsat forskning inden for feltet. Hvis udgangspunktet er erhvervslivets behov for medarbejdere med it-kompetencer på universitetsniveau og at universiteterne har kapaciteten til at uddanne sådanne kandidater, kunne følgende temaer være indgange til fortsat debat og forskning:

Hvordan kan styredokumenter udformes, hvis overgangsudfordringer skal indfanges?

Hvordan kan underviserne udvikle deres it-kompetencer?

Hvordan kan elever i grundskolen og gymnasiet "få øje " på it som en faglighed og som en mulig profession og karrierevej?

Hvordan kan erhvervslivet berige uddannelsessystemet med den intention, at få elever gjort interesserede i it-faglighed?

Hvordan kan kønsfordelingen på de specifikt datalogisk orienterede uddannelser ændres i retning af at flere kvindelige studerende søger optagelse? (Erhvervslivet efterspørger specielt kvinder inden for datalogifeltet)

\section{Referencer}

Luhmann, N. (1988). Erkenntnis als Konstruktion. Berlin: Benteli Verlag

Luhmann, N. (1997). Iagttagelse og paradoks. Kbh.: Gyldendal

Luhmann, N. (2000). Sociale Systemer. Kbh: Reitzels

Mathiasen, $\mathrm{H}$ et al (2009). Overgangsproblemer som udfordringer $i$ uddannelsessystemet. Århus: IMV

Undervisningsministeriets hjemmeside, www.uvm.dk

Aarhus Universitet: http://www.science.au.dk/12852, http://www. nat.au.dk/13099, http://www.nat.au.dk/13157 
BILAG 1:

Tabel 1: Operationalisering af it-anvendelse og itfaglighed på grundlag af styredokumenterne

Der er ingen sammenhæng i tabellens rækker hvad angår uddannelsesniveauerne.

\begin{tabular}{|c|c|c|c|c|}
\hline \multicolumn{2}{|l|}{ Grundskole-niveau } & \multicolumn{2}{|l|}{ Stx-niveau } & \multirow{2}{*}{$\begin{array}{l}\text { Universitets-niveau } \\
\text { It-faglighed }^{3}\end{array}$} \\
\hline It-anvendelse & It-faglighed & $\begin{array}{l}\text { It-anvendelse } \\
\text { (alle fag) }\end{array}$ & $\begin{array}{l}\text { It-faglighed } \\
\text { (valgfag) }\end{array}$ & \\
\hline Anvendelse af computeren & $\begin{array}{l}\text { 'Får forståelse for, hvor- } \\
\text { dan teknologi og sam- } \\
\text { fundsudvikling hænger } \\
\text { sammen' (valgfag) }\end{array}$ & $\begin{array}{l}\text { Kommunikationsmiddel, ud- } \\
\text { tryksmiddel, } \\
\text { Billedreproduktivt medie }\end{array}$ & von Neuman princip & $\begin{array}{l}\text { Programmering, algoritmer } \\
\text { og datastrukturer }\end{array}$ \\
\hline $\begin{array}{l}\text { Gennemførelse af bereg- } \\
\text { ninger }\end{array}$ & $\begin{array}{l}\text { 'Undervisningen skal lede } \\
\text { frem imod at eleverne } \\
\text { har tilegnet sig kundska- } \\
\text { ber og færdigheder i edb- } \\
\text { faglige metoder og begreber } \\
\text { (...)' (valgfag) } \\
\end{array}$ & $\begin{array}{l}\text { 'It indgår som en integreret } \\
\text { del af undervisningen og } \\
\text { anvendes til bl.a. kommu- } \\
\text { nikation, dataopsamling og } \\
\text { databehandling.' }\end{array}$ & $\begin{array}{l}\text { Repræsentation } \\
\text { og strukturering af } \\
\text { data, algoritme be- } \\
\text { grebet, }\end{array}$ & $\begin{array}{l}\text { Interaktionsdesign, menne- } \\
\text { ske-maskine interaktion }\end{array}$ \\
\hline Ved hjælp af computeren & $\begin{array}{l}\text { ‘...hvor og hvordan det } \\
\text { er hensigtsmæssigt at } \\
\text { anvende de informations- } \\
\text { teknologiske skrive- og } \\
\text { kommunikationsred- } \\
\text { skaber ... og forstå } \\
\text { tekstbehandlingens sam- } \\
\text { fundsmæssige betydning.' } \\
\text { (valgfag) }\end{array}$ & $\begin{array}{l}\text { 'Der lægges vægt på inddra- } \\
\text { gelse af it i undervisningen i } \\
\text { forbindelse med: } \\
\text { - skrivning og præsentation } \\
\text { - informationssøgning } \\
\text { - interaktive programmer til } \\
\text { sproglære } \\
\text { - virtuelle konferencer' }\end{array}$ & $\begin{array}{l}\text { Grænseflader og } \\
\text { protokoller, pro- } \\
\text { grammering og } \\
\text { afprøvning, } \\
\text { netværk, kommuni- } \\
\text { kation og sikkerhed, } \\
\text { arkitektur }\end{array}$ & $\begin{array}{l}\text { Webteknologi, distribuerede } \\
\text { systemer, web og hyperme- } \\
\text { dier, mulitmedier }\end{array}$ \\
\hline Benytte computeren & $\begin{array}{l}\text { 'Undervisningen skal give } \\
\text { eleverne mulighed for at } \\
\text { opnå viden om teknolo- } \\
\text { giens betydning for egne } \\
\text { og andres levevilkår og } \\
\text { livsstil.' (valgfag) }\end{array}$ & $\begin{array}{l}\text { 'Eleverne skal bruge elek- } \\
\text { tronisk kommunikation og } \\
\text { videndeling' }\end{array}$ & $\begin{array}{l}\text { Grundlæggende } \\
\text { funktioner af it- } \\
\text { komponenter }\end{array}$ & $\begin{array}{l}\text { Computere og netværk, soft- } \\
\text { ware arkitektur, fysisk design }\end{array}$ \\
\hline Udføre simuleringer & & $\begin{array}{l}\text { 'It som støtteredskab ... for } \\
\text { arbejdet med den færdig- } \\
\text { hedsmæssige side af sprog- } \\
\text { tilegnelsen' }\end{array}$ & $\begin{array}{l}\text { Sikkerhed og risi- } \\
\text { kofaktorer ved et } \\
\text { it-system }\end{array}$ & Operativsystemer \\
\hline $\begin{array}{l}\text { Organisere, tydeliggøre og } \\
\text { præsentere information }\end{array}$ & & $\begin{array}{l}\text { '...og bearbejdning af faglig } \\
\text { information fra internettet.' }\end{array}$ & $\begin{array}{l}\text { Grundlæggende } \\
\text { sammenspil mellem } \\
\text { it-komponenter og } \\
\text { brugere }\end{array}$ & Regularitet og automater \\
\hline $\begin{array}{l}\text { Arbejdsmåder og tanke- } \\
\text { gange > udnytte it's mu- } \\
\text { ligheder }\end{array}$ & & $\begin{array}{l}\text { '...skaffe sig viden om...' 'In- } \\
\text { ternettet og andre elektro- } \\
\text { niske medier skal inddrages } \\
\text { som kilde...' }\end{array}$ & $\begin{array}{l}\text { Visuelt design, audi- } \\
\text { tivt design, interakti- } \\
\text { vitet, hypermedier, }\end{array}$ & $\begin{array}{l}\text { Beregnelighed og logik, } \\
\text { optimering, kombinatorisk } \\
\text { søgning }\end{array}$ \\
\hline Bruge it & & $\begin{array}{l}\text { '...til at støtte og supplere } \\
\text { de faglige mål og den pæda- } \\
\text { gogiske proces.' }\end{array}$ & $\begin{array}{l}\text { Infrastruktur, trans- } \\
\text { port af data, databa- } \\
\text { ser og datarepræ- } \\
\text { sentation }\end{array}$ & $\begin{array}{l}\text { Systemudvikling, metoder og } \\
\text { proces, projektledelse, ud- } \\
\text { vikle til en brugssituation, }\end{array}$ \\
\hline $\begin{array}{l}\text { Udnytte it og mediers } \\
\text { muligheder i forbindelse } \\
\text { med informationssøgning } \\
\text { og kommunikation }\end{array}$ & & $\begin{array}{l}\text { ‘...it og matematikprogram- } \\
\text { mer bliver væsentlige hjælpe- } \\
\text { midler }(\ldots)\end{array}$ & $\begin{array}{l}\text { Læse enkle pro- } \\
\text { grammer og re- } \\
\text { degøre for deres } \\
\text { funktionsmåde }\end{array}$ & $\begin{array}{l}\text { Matematisk modellering, cal- } \\
\text { cus I+2 (statistik) }\end{array}$ \\
\hline $\begin{array}{l}\text { 'Eleverne tilegner sig viden } \\
\text { om informationsteknolo- } \\
\text { giens betydning for skrive- } \\
\text { og kommunikationspro- } \\
\text { cessen' }\end{array}$ & & $\begin{array}{l}\text { (valgfag): præsentere og for- } \\
\text { midle data og informationer } \\
\text { ved brug af it, anvende it } \\
\text { som interaktivt medie til } \\
\text { dokumentation og kommu- } \\
\text { nikation }\end{array}$ & $\begin{array}{l}\text { Anvende eksisteren- } \\
\text { de programdele fra } \\
\text { et bibliotek, udvikle } \\
\text { enkle programmer }\end{array}$ & $\begin{array}{l}\text { Store It-innovationer, for- } \\
\text { rentningscases, it i samfun- } \\
\text { det, kunne organisere og } \\
\text { deltage i teknologiske foran- } \\
\text { dringer i organisationer sam- } \\
\text { men med berørte parter }\end{array}$ \\
\hline
\end{tabular}

\section{Noter}

1 Undersøgelsen udføres af it-forum Midtjylland og kan rekvireres ved henvendelse hertil.
2 Andersen, Bendixen, Dahl, Enggaard, Kølsen, Lindenskov, Mathiasen, Misfeldt, Ågård, 2009 http://www.cil.au.dk/documents/ Overgangsproblemer_2009.pdf

3 It-anvendelse optræder ikke som en del af studieordningerne på det universitære niveau. 